\title{
EKG-gyöngyszem: tranziens De Winter-jel
}

\author{
Tomcsányi János dr. - Arabadzisz Hrisula dr. - Frész Tamás dr. \\ Budai Irgalmasrendi Kórház, Kardiológiai Osztály, Budapest
}

\begin{abstract}
Egy 42 éves férfi akut coronaria szindróma okozta De Winter-féle EKG-jel miatt került sürgősségi osztályra. Az EKG nem megfelelő interpretációja miatt csak három órával később került a katéteres laboratóriumba. Addigra a hiperakut T-hullámok megszúntek, a praecordialis ST-depresszió regrediált, de a cardialis biomarkerek jelentős emelkedést mutattak. A coronarographia a bal elülső leszálló coronaria proximális thromboticus dissectióját mutatta, amely egy gyógyszerkibocsátó sztenttel lett lefedve. A szerzők azért ismertetik ezt az EKG-jelet, mert ilyen esetben - attól függetlenül, hogy nincs ST-szegmens-eleváció - a javasolható kezelés az azonnali coronariaintervenció.
\end{abstract}

Orv Hetil. 2019; 160(43): 1711-1713.

Kulcsszavak: akut coronaria szindróma, De Winter-jel, coronariadissectio

\section{ECG pearl: transient De Winter sign}

\begin{abstract}
A 42 -year-old man is presented with acute coronary syndrome and De Winter ECG sign. The De Winter sign is a rare ECG manifestation of proximal LAD occlusion. The ECG sign was misinterpreted and the patient was transmitted to our percutan coronaria intervention centrum with 3 hours delay. The hyperacute $\mathrm{T}$-waves and the precordial ST-depressions disappeared, but the biomarkers showed a marked elevation. Coronary angiography revealed LAD proximal thrombotic dissection treated with a drug-eluting stent. The authors suggest that in patients with this ECG pattern the immediate coronary intervention is the best treatment.
\end{abstract}

Keywords: acute coronary syndrome, De Winter sign, coronary dissection

Tomcsányi J, Arabadzisz H, Frész T. [ECG pearl: transient De Winter sign]. Orv Hetil. 2019; 160(43): 1711-1713.

(Beérkezett: 2019. május 20.; elfogadva: 2019. június 15.)

\section{Rövidítések}

$\mathrm{CK}=$ (creatine kinase) kreatin-kináz; DES $=$ (drug-eluting stent) gyógyszerkibocsátó sztent; EKG = elektrokardiogram; hs $=($ high-sensitivity) magas szenzitivitású; LAD $=($ left artery descending) bal elülső leszálló coronaria; NSTEMI = (non STelevation myocardial infarction) nem ST-elevációs myocardialis infarctus; $\mathrm{PCI}=$ percutan coronariaintervenció; SBO = Sürgősségi Betegellátó Osztály; STEMI = (ST-elevation myocardial infarction) ST-elevációs myocardialis infarctus

\section{Esetismertetés}

A 42 éves férfi anamnézisében vesekő, kólika, diffúz májlaesio, krónikus hasnyálmirigy-gyulladás szerepel. Napi 30-60 szál cigarettát szív, korábban napi fél liter vodkát ivott, jelenleg alkalmanként fogyaszt sört. Panaszai előző este epigastrialis fájdalommal, vomitussal kezdődtek, majd ezek után hajnali 4 óráig aludt, amikor is nyomó jellegú verejtékezéssel, dyspnoéval járó mellkasi fájdalma kezdődött. A területileg illetékes SBO-n kezdetben jelzett hs-troponin-T-emelkedést $(0,016 \mathrm{ng} /$ ml-t mértek; a referencia kevesebb, mint $0,014 \mathrm{ng} / \mathrm{ml}$ ) láttak praecordialis ST-depresszió és magas csúcsos Thullámok kíséretében. A 3 órás kontrollra a hs-troponinT lényeges emelkedést mutatott $(1470 \mathrm{ng} / \mathrm{ml})$, mialatt az EKG-n az ST-depresszió és a hiperakut T-hullámok megszüntek, és a V2-3-as elvezetésekben QS alakult ki (1. ábra). Az echocardiographia a septum falmozgásának hipoakinézisét mutatta. Ekkor referálták a beteget a PCI Centrumunknak. A beteg érkezési CK-enzim-érté- 
05.00

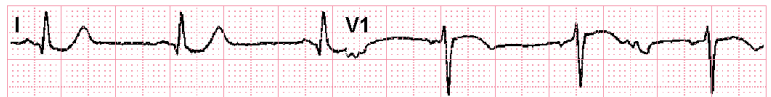

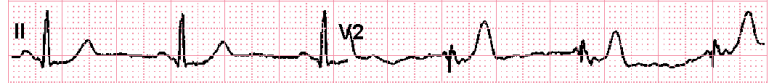

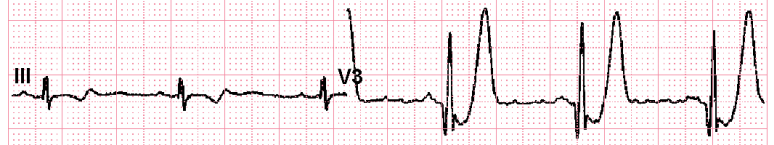
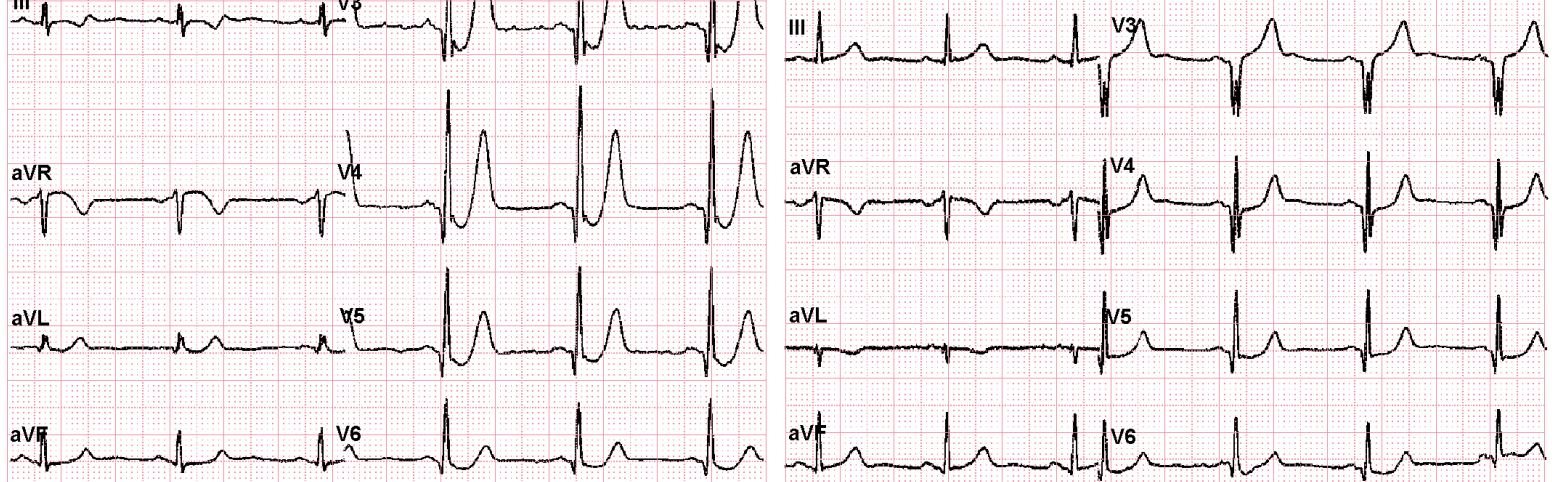
induló ST-depresszió és hiperakut magas T-hullámok láthatók, amelyek 3 órával késóbb megszúntek, és helyettük QS-komplexumokat lehetett látni

$\mathrm{EKG}=$ elektrokardiogram
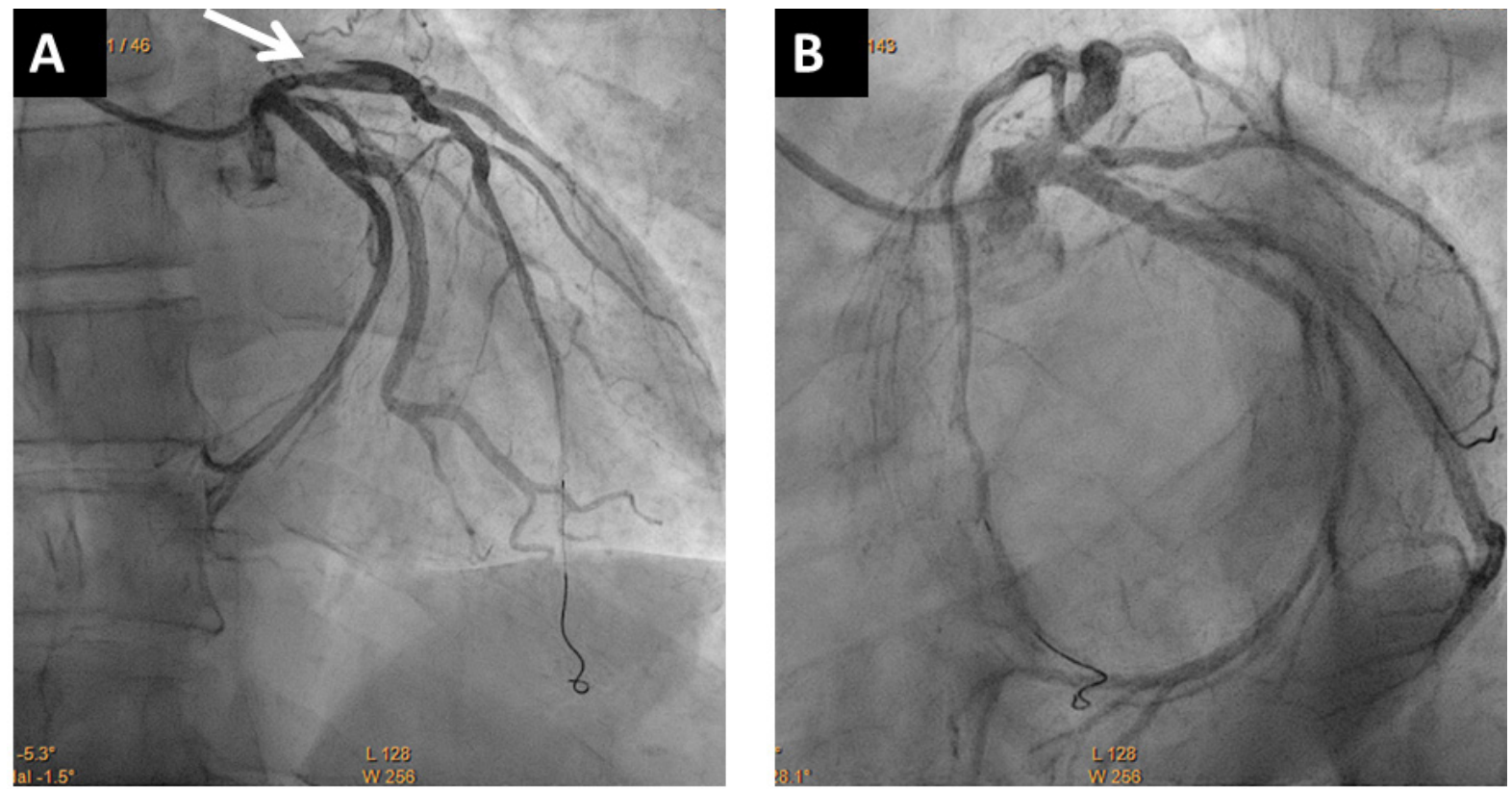

2. ábra

Az A-panelen a LAD proximális szakaszának dissectiója látható (fehér nyíl) anteroposterior (AP) nézetből, percutan coronariaintervenció (PCI) előtt; drót a LAD-ban. A B-panel a PCI utáni állapotot mutatja has felé döntött bal elülső ferde (LAO-CAUD) nézetből. A nyíl a gyógyszerkibocsátó sztenttel fedett proximális LAD-szakaszt mutatja; a kép jobb oldalán drót a Cx 2. marginálisában, a kép bal oldalán drót a distalis LAD-ban

$\mathrm{Cx}=$ circumflexus; $\mathrm{LAD}=$ bal elülső leszálló coronaria

ke már $3700 \mathrm{U} / 1$ (normál: $\leq 170 \mathrm{U} / \mathrm{l}$ ) volt. A coronarographia a LAD spontán thromboticus dissectióját mutatta, amely egy Promus PREMIER DES-sel (Boston Scientific, Marlborough, MA, Amerikai Egyesült Államok) lett lefedve (2. ábra). A beteg korai rehabilitációja eseménytelenül telt.

\section{Megbeszélés}

A nemzetközi ajánlások a nem ST-elevációs myocardialis infarctust (NSTEMI) nem tartják azonnali coronariaintervenciót igénylő kórképnek $[1,2]$. A két órán belüli intervenciót elsősorban a hemodinamikai instabilitáshoz 
kötik, míg a többi esetben a 72 órán belüli revascularisatiót javasolják [2]. Ugyanakkor a NSTEMI-k egy nem elhanyagolható részében teljes coronariaocclusio van, amelyeknél jó lenne a mielőbbi coronariaintervenció, mert ezeknek a betegeknek magasabb a mortalitásuk [3]. Ezen betegek kiszűrése különösen fontos lenne hazánkban, mert ismert, hogy a régió egyik legrosszabb mortalitási adataival rendelkezünk a kórházi elbocsátás után. A NSTEMI-k egyik csoportja a hiperakut T-hullámmal járó praecordialis ST-depresszió EKG-mintázatát mutatja, amelyek hátterében a proximális LAD-occlusio áll. A jelenséget először Dressler írta le [4], de gyakoriságát és jelentőségét napjainkban De Winter és mtsai közölték, ezért is hívják ezt az EKG-megjelenést De Winter-jelnek $[5,6]$, habár helyesebb lenne a Dressler-De Winter elnevezés [7]. Klinikai jelentősége, hogy egy STEMI-ekvivalens magas rizikójú betegcsoportot jelez a LAD proximális elzáródása miatt $[8,9]$.

Esetünkben egy proximális LAD-dissectio okozta a De Winter-jelet (nem kizárt, hogy a vomitussal járó fokozott intrathoracalis nyomás fokozódása is szerepet játszott a dissectio kialakulásában). Ha a De Winter-féle EKG-jel időben kerül felismerésre, akkor valószínúleg még a teljes occlusio detektálása mellett jelentős szívizomtömeg megmenthető lett volna, aminek a későbbi prognózisra is jelentős hatása van. Egy nemrég megjelent metaanalízis azt igazolta, hogy a De Winter-jel igen magas prediktivitással rendelkezik az akut occlusióra [10]. Esetünket azért tartottuk fontosnak a bemutatásra, hogy javítsuk az akut coronaria szindrómát először ellátó orvosok EKG-felismerő képességét, és csökkentsük a hibás interpretáció előfordulását [11]. Habár nem rendelkezünk összehasonlító adatokkal arról, hogy az azonnali revascularisatio javítja-e a mortalitást [10], erre vonatkozóan valószínúleg nem is lesznek vizsgálatok, mert egy nagy szívizomterületet ellátó coronaria elzáródásakor mindenki az urgens intervenciót, az ér azonnali megnyitását tartja indokoltnak [12].

Anyagi támogatás: A szerzők a cikk megírásával kapcsolatban anyagi támogatásban nem részesültek.

Szerzői munkamegosztás: T. J.: Irodalomkutatás, a cikk megírása. A. H.: A beteg kezelése. F. T.: Az intervenció elvégzése. A cikk végleges változatát valamennyi szerző elolvasta és jóváhagyta.

Érdekeltségek: A szerzőknek a cikkel kapcsolatban nincsenek érdekeltségeik.

\section{Irodalom}

[1] Roffi M, Patrono C, Collett JP, et al. 2015 ESC Guidelines for the management of acute coronary syndromes in patients presenting without persistent ST-segment elevation: Task Force for the Management of Acute Coronary Syndromes in Patients Presenting without Persistent ST-Segment Elevation of the European Society of Cardiology (ESC). Eur Heart J. 2016; 37: 267315.

[2] Sousa-Uva M, Neumann FJ, Ahlsson A, et al. 2018 ESC/ EACTS guidelines on myocardial revascularization. Eur J Cardiothorac Surg. 2019; 55: 4-90.

[3] Khan AR, Golwala H, Tripathi A, et al. Impact of total occlusion of culprit artery in acute non-ST elevation myocardial infarction: a systemic review and meta-analysis. Eur Heart J. 2017; 38: 3082-3089.

[4] Dressler W, Roesler H. High T waves in the earliest stage of myocardial infarction. Am Heart J. 1947; 34: 627-645.

[5] De Winter RJ, Verouden NJ, Wellens HJ, et al. A new ECG sign of proximal LAD occlusion. N Engl J Med. 2008; 359: 20712073.

[6] Verouden NJ, Koch KT, Peters RJ, et al. Persistent precordial "hyperacute" T-waves signify proximal left anterior descending artery occlusion. Heart 2009; 95: 1701-1706.

[7] Littmann L. The Dressler-De Winter sign of acute proximal LAD occlusion. J Electrocardiol. 2018; 51: 138-139.

[8] Tomcsányi J, Nényei Z, Sármán B, et al. A new ECG marker of anterior acute myocardial infarction. (Az akut anterior myocardialis infarctus új EKG-jele.) Orv Hetil. 2010; 151: 387-389. (Hungarian)

[9] Sheng F, He M, Zhang M, et al. A STEMI equivalent of De Winter sign missed by an emergency physician. J Electrocardiol. 2016; 49: 620-622.

[10] Morris NP, Body R. The De Winter ECG pattern: morphology and accuracy for diagnosing acute coronary occlusion: systemic review. Eur J Emerg Med. 2017; 24: 236-242.

[11] Birnbaum Y, Bayés de Luna A, Fiol M, et al. Common pitfalls in the interpretation of electrocardiograms from patients with acute coronary syndromes with narrow QRS: a consensus report. J Electrocardiol. 2012; 45: 463-475.

[12] Qayyum H, Hermaya S, Squires J, et al. Recognising the De Winter ECG pattern - a time critical electrocardiographic diagnosis in the Emergency Department. J Electrocardiol. 2018; 51: 392-395.

(Tomcsányi János dr., Budapest, Árpád fejedelem útja 7., 1027 e-mail: tomcsanyij@gmail.com) 